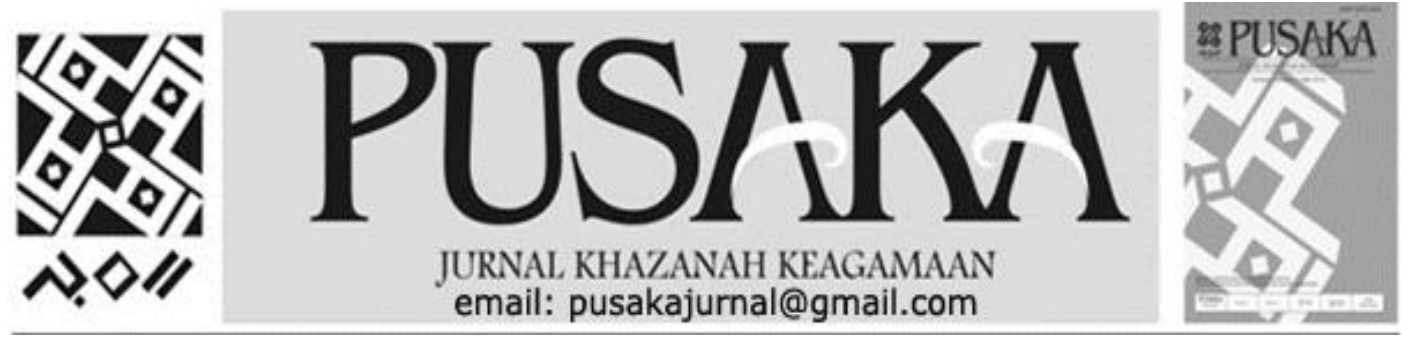

\title{
Implementasi Pendidikan Agama Islam Pada Pendidikan Anak Usia Dini (PAUD)
}

Implementation of Islamic Education in Early Childhood Education (PAUD)

Wahab

Balai Penelitian dan Pengembangan Agama Semarang

Jl.Untung Suropati Kav.70 Bambangkerep Ngaliyan Semarang

Email:wahab.alba@gmail.com

\begin{tabular}{|c|c|}
\hline $\begin{array}{c}\text { Info } \\
\text { Artikel }\end{array}$ & Abstract \\
\hline $\begin{array}{c}\text { Diterima } \\
09 \\
\text { Maret } \\
2018 \\
\text { Revisi I } \\
12 \\
\text { April } \\
2018 \\
\\
\text { Revisi II } \\
23 \\
\text { April } \\
2018\end{array}$ & 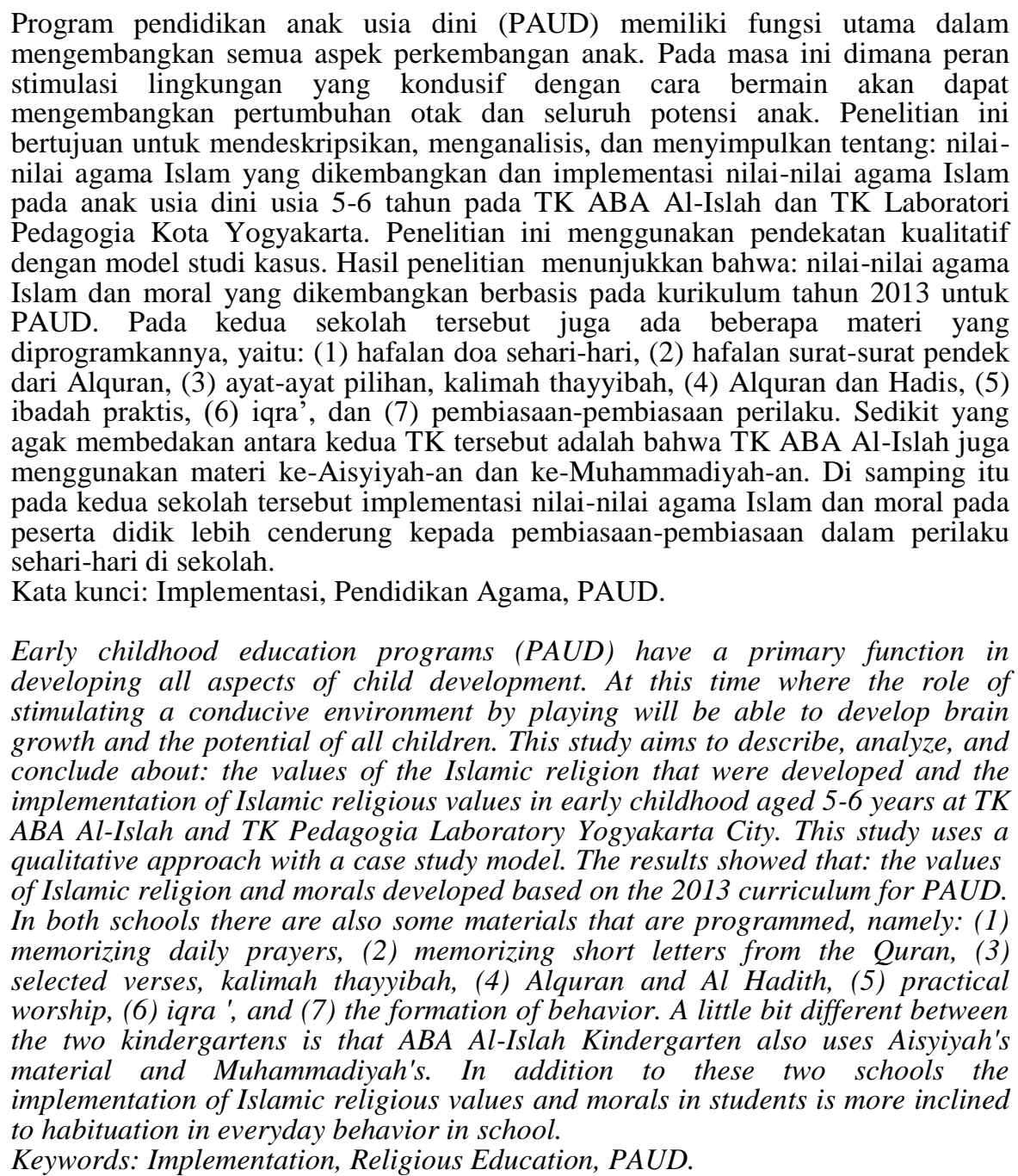 \\
\hline
\end{tabular}




\section{PENDAHULUAN}

Menurut UU No. 20 Tahun 2003 tentang Sistem Pendidikan Nasional Bab 1, pasal 1, butir 14 dinyatakan bahwa "Pendidikan Anak Usia Dini adalah suatu upaya pembinaan yang ditujukan kepada anak sejak lahir sampai dengan usia enam tahun yang dilakukan melalui pemberian rangsangan pendidikan untuk membantu pertumbuhan dan perkembangan jasmani dan rohani agar anak memiliki kesiapan dalam memasuki pendidikan lebih lanjut". Kemudian dalam pasal 28 tentang (PAUD) pendidikan anak usia dini dinyatakan bahwa pendidikan anak usia dini diselenggarakan sebelum jenjang pendidikan dasar, dapat diselenggarakan melalui jalur pendidikan formal, nonformal, dan atau informal.

Permendikbud Nomor 137 Tahun 2014 tentang Standar Nasional Pendidikan Anak usia Dini, Pasal 35 menyebutkan bahwa: pelaksanaan program PAUD merupakan integrasi dari layanan pendidikan, pengasuhan, perlindungan, kesehatan dan gizi yang diselenggarakan dalam bentuk satuan atau program Taman Kanakkanak (TK)/Raudatul Athfal (RA), Bustanul Athfal (BA), Kelompok Bermain (KB), Taman Penitipan Anak (TPA), dan Satuan PAUD Sejenis (SPS).

Pasal 36, dalam Permendikbud tersebut di atas juga disebutkan pada Ayat: (1) kegiatan layanan PAUD meliputi jenis layanan, waktu kegiatan, frekuensi pertemuan, rasio guru dan anak, (2) jenis layanan sebagaimana dimaksud pada ayat 1 terdiri atas: a. usia lahir-2 tahun dapat melalui TPA dan atau SPS; b. usia 2-4 tahun dapat melalui TPA, KB dan atau SPS; dan c. usia 4-6 tahun dapat melalui KB, TK/RA/BA, TPA, dan atau SPS. (3) waktu kegiatan sesuai usia dan frekuensi pertemuan sebagaimana dimaksud pada ayat 1 terdiri atas: usia lahir-2 tahun: satu kali pertemuan minimal 120 menit, dengan melibatkan orang tua, dan frekuensi pertemuan minimal satu kali per minggu, usia 24 tahun: satu kali pertemuan minimal 180 menit dan frekuensi pertemuan minimal dua kali per minggu, dan usia 4-6 tahun: satu kali pertemuan minimal 180 menit dan frekuensi pertemuan minimal lima kali per minggu, (4) rasio guru dan anak didik sebagaimana dimaksud pada ayat1 terdiri atas: usia lahir-2 tahun: rasio guru dan peserta didik 1:4, Usia 2-4 tahun: rasio guru dan peserta didik 1:8, dan usia 4-6 tahun: rasio guru dan peserta didik 1:15.

Berbagai manfaat yang akan dirasakan oleh si kecil setelah mendapatkan pendidikan di playgroup atau TK adalah: (1) memperkenalkan anak pada dunia sekolah, (2) membiasakan anak terhadap kegiatan terstruktur, (3) mengajari anak untuk disiplin dan mengikuti peraturan,(4) menumbuhkan imajinasi dan kreativitas, (5) menanamkan nilainilai positif, (6) membentuk dasar kepribadian anak (pauddikmas.kemendikbud.go.id, diakses pada tanggal 27 Desember 2017).

Mengingat penelitian ini dilakukan di Daerah Istimewa Yogyakarta, maka berikut ini dikemukakan deskripsi eksitensi TK/PAUD di daerah tersebut. Data statistik di Propinsi Daerah Istimewa Yogyakarta menunjukkan bahwa 
layanan untuk Pendidikan Anak Usia Dini (PAUD) pada setiap desa tercatat mencapai 100\%. Artinya bahwa setiap desa di Daerah Istimewa Yogyakarta telah memiliki PAUD (Lihat: data Kemendikbud tahun 2013/2014).

Bagi anak-anak usia dini penanaman nilai-nilai agama dan moral merupakan hal yang sangat urgen sebagai upaya mendasari anakanak agar memiliki budi pekerti yang luhur (akhlakul karimah). Pada kurikulum tahun 2013 PAUD dijelaskan bahwa pendidikan agama bagi anak usia dini merupakan Kompetensi Dasar (KD) sikap spiritual tersebut. Implementasi (pelaksanaan) adalah merupakan proses, cara, perbuatan melaksanakan (rancangan, keputusan, dan sebagainya (Tim Penyusun Kamus Pusat Pembinaan dan Pengembangan Bahasa Depdikbud, 1989: 488). Adapun pelaksanaan yang dimaksud dalam pembahasan ini adalah pelaksanaan Pendidikan Agama Islam (PAI) pada Pendidikan Anak Usia Dini (PAUD) yang meliputi nilai-nilai agama yang dikembangkan, implementasi nilainilai agama, dan faktor-faktor pendukung maupun penghambat dalam implementasi pendidikan agama. Dalam hal ini fokus penelitian adalah TK ABA Al-Islah dan TK Laboratori Pedagogia Kota Yogyakarta.

Pendidikan dapat didefinisikan sebagai keseluruhan pengalaman belajar setiap orang sepanjang hidupnya yang berlangsung tidak dalam batas usia tertentu tetapi berlangsung sepanjang hidup sejak lahir hingga mati (Mudyahardjo, 2002 : 46). Pendidikan juga dalam rangka menumbuhkan peserta didik ke arah nilai-nilai masyarakat, sebagaimana pendapat Satori (2017:115) bahwa pendidikan adalah situasi dimana terjadi dialog antara peserta didik dengan pendidik yang memungkinkan peserta didik tumbuh ke arah yang dikehendaki oleh pendidik agar selaras dengan nilainilai yang dijunjung tinggi masyarakat.

Zuhairini (2000: 27) menjelaskan bahwa pendidikan agama berarti usaha-usaha secara sadar dan pragmatif membantu anak didik supaya mempunyai ilmu pengetahuan agama. Definisi tersebut relevan dengan isi dari Pasal 30, ayat 2 Undang-Undang Nomor 20 tentang Sisdiknas yang menjelaskan bahwa pendidikan keagamaan berfungsi menyiapkan peserta didik menjadi anggota masyarakat yang memahami dan mengamalkan nili-nilai ajaran agamanya dan/atau menjadi ahli agama.

Penelitian ini menggunakan pendekatan kualitatif. Alasan penggunaan pendekatan ini adalah dengan pertimbangan lebih dapat mengungkap hakikat yang sebenarnya implementasi Pendidikan Agama Islam (PAI) pada Pendidikan Anak Usia Dini (PAUD), khususnya PAUD yang menjadi percontohan/gugus. Adapun model penelitian yang digunakan adalah studi kasus.

Alasan penelitian ini menggunakan pendekatan kualitatif adalah pendekatan kualitatif bersifat eksploratif. Creswel, dalam (Sugiyono, 2013: 347-348) menyatakan bahwa penelitian dengan kualitatitf berarti proses eksploratif dan memahami makna perilaiku 
individu dan kelompok, menggambarkan masalah sosial atau kemanusiaan. Proses penelitian itu mencakup membuat pertanyaan penelitian dan prosedur yang bersifat sementara, mengumpulkan data pada seting partisipan, analisis data secara induktif, membangun data yag parsial ke dalam tema, dan selanjutnya memberikan interpretasi terhadap makna suatu data.

Analisis yang digunakan dalam peneliitian ini adalah model analisis interaksi. Menurut Strauss yang dinukil oleh Wahab (2011: 46) menjelaskan bahwa model analisis interaksi adalah menghubungkan antara kategori dengan sub kategori untuk kemudian dicari pola-polanya. Adapun langkah-langkah yang harus ditempuh dalam analisis dengan pendekatan kualitatif ini adalah melalaui reduksi data, penyajian data, dan verifikasi data (Sugiyono, 2005: 92).

Analisis dalam penelitian ini akan dilakukan dengan dua tahap, yaitu selama di lapangan dan setelah dari lapangan. Analisis selama di lapangan ada beberapa langkah yang ditempuh, yaitu: mempersempit fokus studi dengan maksud mempersempit skop penelitian serta membatasi data yang dikumpulkan, menetapkan tipe studi, mengembangkan pertanyaan analitik, dan menyusun komentar. Sedangkan analisis setelah dari lapangan adalah membuat kategori masalah/temuan dan menata sekuensi atau urutan penelaahannya. Lebih sederhananya sebagaimana pendapat Miles dan Huberman yang dinukil oleh Wahab (2008: 9) bahwa tahapan analisis data kualitatif itu dilakukan melalui tiga tahap, yaitu: reduksi data, penyajian data, dan menarik simpulan/verifikasi.

\section{PEMBAHASAN \\ Profil Singkat TK/PAUD ABA Al- Islah}

TK/PAUD ABA Al-Islah berada di Jalan Nyi Adisari Pilahan, RT 40 RW 12, Kelurahan Rejowinangun, Kota Gede, Yogyakarta.TK/PAUD ABA AlIslah berdiri pada tanggal 09 Julai 1990 dengan nama TK/PAUD ABA Al-Islah. Pengelolaan TK/PAUD tersebut pada mulanya ditangani oleh Takmir Masjid Al-Islah yang sekaligus sebagai pendirinya. Kegiatan Belajar Mengajar (KBM) pada mulanya menempati pendopo rumah Bapak Djupriyanto yang keberadaannya di sebelah utara Masjid Al-Islah dengan dua orang pendidik dan 32 orang peserta didik. KBM dilaksanakan mulai pukul 07.30-10.00 WIB. Berkat kegigihan Takmir masjid bersama PRA Pilihan melaksanakan pembangunan gedung yang dimulai pada tanggal 01 Desember 2003. Pada tanggal 27 Desember 2003 akhirnya gedung baru tersebut resmi digunakan.

Pada Bulan Juli tahun 2007 TK/PAUD ABA Al-Islah mendapatkan dana Block Grand sebagai TK Pembina Kecamatan. Dana tersebut digunakan untuk membangun lagi ruang kelas, ruang perpustakaan, ruang UKS, ruang penjaga, aula, kolam renang dan lain sebagainya yang selesai pada tahun 2008. Pada tahun ajaran 2016/2017, lembaga pendidikan tersebut melayani pendidikan untuk masyarakat, yakni KBA (Kelompok Bermain Anak usia 2,5-4 tahun) sebanyak 13 orang, TAA (Taman 
Asuh Anak) sebanyak 21 orang, dan TK/PAUD A dan B dengan peserta didik sebanyak 108 (laki-laki 63 orang dan perempuan 45 orang). Jumlah pendidik yang berstatus sebagai tenaga tetap sebanyak 12 orang (4 orang DPK dan 8 orang tenaga yayasan) dan 8 tenaga pendidik ekstra kurikuler. Sedangkan tenaga kependidikan yang terdiri tenaga TU, pesuruh, dan penjaga malam sebanyak 5 orang (Sumber: Profil TK ABA Al-Islah Tahun Ajaran 2017).

\section{Profil Singkat TK/PAUD Laboratori Pedagogia}

Sejak tahun 1996 di FIP UNY berdiri program studi PGTK yang outputnya adalah pendidik TK/PAUD. Pada tahun 2005, nama PGTK UNY semakin mendapat pengakuan dari masyarakat. Pada akhirnya KB-TK Laboratori Pedagogi didirikan pada tanggal 31 Desember 2005. Selanjutnya PGTK yag awalnya Prodi Diploma berkembang menjadi Program Sarjana PG PAUD sejak tahun 2008.

TK Laboratori Pedagogi berada di Jalan Bantul No. 50 Kelurahan Gedongkiwo, Kecamatan Mantrijeron, Kota Yogyakarta, Propinsi Daerah Istimewa Yogyakarta. TK/PAUD Laboratori memiliki 8 orang pendidik, 7 guru konselor-individual-pendamping khusus, dan tenaga terapis sebanyak 3 orang. Semua pendidik dan tenaga kependidikaan TK/PAUD Laboratori berstatus swasta (yayasan). Jumlah peserta didik pada tahun ajaran 2017/2018 sebanyak 67 orang, dengan perincian: peserta didik kelas A sebanyak 25 orang (2 rombel), peserta didik kelas B 30 orang (2 rombel), dan peserta didik berkebutuhan khusus 12 orang.

Status TK Laboratori Pedagoia adalah swasta, dengan nomor Akta Pendirian: SK Rektor UNY No. 537 Tahun 2010, Nomor Izin: 118/3599a Tetanggal 31 Desember 2005, NSS: 012046008014, NPSN: 20409081. Alamat AT Laboratori Pedagogia adalah: Jalan bantul No. 50, Kelutahan Gedongkiwo, Kecamatan Mantrijeron, Kota Yogyakarta, Propinsi Daerah Istimewa Yogyakarta (Sumber: Profil TK Laboratori Pedagogia FIP YNY, Tahun Ajaran 2017-2018).

\section{Karakteristik Kurikulum TK ABA Al-Islah}

Lembaga pendidikan TK/PAUD ABA Al-Islah program kegiatan dan proses pembelajarannya menggunakan Kurikulum Tahun 2013. Selain itu dalam pelaksanaan pembelajaran sehari-hari ada kegiatan yang menjadi program rutin yaitu: Ke-Muhammadiyah-an dan ekstra kurikuler yang meliputi: iqra', Bahasa Inggris, drum band, menari, renang, dan melukis. Kemudian ada juga materi tambahan sebagai program unggulan yang meliputi: hafalan Alquran (tahfidz Alquran), hafalan surat pendek, ayat-ayat pilihan dan kalimah thayyibah, ibadah praktis, dan pembiasaan perilaku.

Dalam rangka mengembangkan dan meningkatkan kualitas pendidikan, PAUD/TK ABA Al-Islah melakukan kerjasama dengan beberapa pihak, antara lain dengan Kelompok Tani Retno Makmur, Kelompok Wani Tani Sinta Mina Pilahan untuk praktek menanam sayur, wiwitan, serta 
praktek panen. Kegiatan lain dalam rangka pengenalan budaya pada sekolah tersebut juga diajarkan wayang thengkling, gejog lesung, edan-edanan, prajurit, gunungan, dan makanan tradisional. Selain program yang sesuai dengan Kurikulm Tahun 2013 yang diterapkan sehari-hari dalam proses pembelajaran, PAUD/TK ABA Al-Islah juga memilki program rutin, yaitu: Peringatan Hari Besar Islam (PHBI), Posenita, akhir sanah (tutup tahun), out bond, pengajian anak, dan bakti sosial. disamping itu, sekolah ini juga memiliki program unggulan seperti yang disebutkan sebelumnya. (lihat: Buku Proses Pembelajaran dan Kurikulum TK ABA Al-Islah Yogyakarta, 2017/2018: 6).

\section{Karakteristik Kurikulum TK Laboratori Pedagogia}

Kurikulum TK Laboratori Pedagogia dirancang dan disusun dengan menerapkan prinsip-prinsip sebagai berikut: 1) mengedepankan keseimbangan pengembangan sikap sosial, emosional, pengetahuan, dan keterampilan, dikembangkan memperhatikan

2) kurikulum dengan keseimbangan pengembangan sikap sosial, pengembangan emosional pengetahuan, dan keterampilan sesuai dengan tahapan perkembangan anak. Dengan memperhatikan keseimbangan sosial, emosional, pengetahuan, dan keterampilan diharapkan menjadi fondasi yang kuat untuk membentuk sikap dan karakter peserta didik untuk mendukung pengembangan sikap spiritual, 3) belajar seraya bermain. Usia anak-anak adalah usia bermain dan dari bermain itu anak memperoleh pengalaman sebagai hasil belajar. Kurikulum TK Laboratori Pedagogia mengembangkan proses membangun pengalaman bersifat aktif. Anak terlibat langsung dalam kegiatan bermain yang menyenangkan. Selama bermain anak menggunakan ide-idenya, belajar mengambil keputusan dan memecahkan masalah sederhana, 4) mempertimbangkan cara belajar anak. Kurikulum mengakomodasi pelaksanaan pembelajaran yang memungkinkan anak membentuk pengalaman belajar dengan cara belajar anak. Anak belajar mulai dari dirinya kemudian ke keluar dirinya, dari kongkrit ke abstrak, sederhana ke kompleks, mudah ke sulit yang dilakukan dengan cara melakukannya sendiri, 5) memperhatikan kelestarian budaya. Kurikulum memper-timbangkan lingkungan yang telah dimiliki anak dengan pengalaman baru untuk membentuk konsep baru. Lingkungan sosial dan budaya berperan sebagai sumber belajar bagi anak yag diharapkan dapat memupuk pengembangan sikap cinta tanah air dan budaya. Kurikulum TK Laboratori Pedagogia disusun dengan mengintegrasikan pendidikan budaya, yang tertuang dalam perencanaan mulai dari penyusunan silabus sampai dengan perencanaan kegiatan, 6) mengenalkan disiplin lalu lintas. Pendidikan anak usia dini berfokus pada stimulasi anak, terutama perkembangan mentalintelektual dan social-emosional. Membangun kedispilinan merupakan bagian stimulasi mental-intelektual anak. Kurikulum TK Laboratori Pedagogia mengusung pengenalan kedisiplinan berlalu lintas, dan 7) 
mengenalkan keberagaman. TK Laboratori Pedagogia telah dikembangkan menjadi lembaga inklusi. Menurut salah seorang ahli, lembaga inklusi adalah lembaga yang mengakomodasi semua anak tanpa memandang kondisi anak secara pisik, intelektual, sosial, emosional, linguistik atau kondisi lainnya, termasuk bagi anak-anak yang berkebutuhan khusus/ABK (Kurikulum Taman Kanak-Kanak TK Laboratori Pedagogia Yogyakarta Tahun Pelajaran 2017/2018: 16-17).

Sebagaimana sudah dipaparkan data tentang implementasi Pendidikan Agama Islam pada TK/PAUD ABA Al Islam di awal, bahwa implementasi Pendidikan Agama Islam pada sekolah tersebut terintegrasi dengan pelaksanaan pembelajaran reguler di kelas. Hal itu menunjukkan bahwa implementasi Pendidikan Agama Islam tidak dilakukan secara spesifik dengan materi pembelajaran agama Islam saja pada waktu tersendiri di luar jam pembelajaran reguler.

\section{Implementasi Kurikulum}

Arikunto, yang dinukil oleh Wahab (2008: 9) menjelaskan bahwa keberhasilan dalam dunia pendidikan tidak terlepas dari beberapa unsur yag mempengaruhi, yaitu: guru, siswa, bahan pelajaran, metode belajar mengajar, sistem evaluasi, sarana penunjang, dan sistem administrasi. Selain itu faktor yang cukup menetukan keberhasilan dalam pendidikan adalah pelaksanaan kurikukulum, karena kurikulum merupakan acuan implementasi kegiatan pendidikan secara terprogram, terencana, dan terstruktur agar pembelajaran berjalan secara terarah.

Implementasi (pelaksanaan) adalah merupakan proses, cara, perbuatan melaksanakan (rancangan, keputusan, dan sebagainya (Tim Penyusun Kamus Pusat Pembinaan dan Pengembangan Bahasa Depdikbud, 1989: 488). Adapun pelaksanaan yang dimaksud dalam pembahasan ini adalah pelaksanaan Pendidikan Agama Islam (PAI) pada Pendidikan Anak Usia Dini (PAUD) yang meliputi nilai-nilai agama yang dikembangkan, implementasi nilainilai agama, dan faktor-faktor pendukung maupun penghambat dalam implementasi pendidikan agama.

Implementasi tersebut di atas sudah barang tentu tidak bisa lepas dengan kurikulum yang digunakan pada lembaga PAUD itu sendiri. Menurut Nurudin yang dinukil oleh Wahab (2008: 9) bahwa pelaksanaan kurikulum itu merupakan proses aktualisasi kurikulum potensial menjadi kurikulum aktual oleh guru atau staf pengajar dalam proses belajar mengajar.

Pengimplementasian kurikulum tidak bisa dilakukan secara asal-asalan, tetapi secara akademik pelaksanaan kurikulum harus berpijak pada sebuah landasan yang sudah ditetapkan dan disahkan oleh lembaga pendidikan yang berkompeten. Dalam rangka mencapai implementasi kurikulum yang baik menuntut adanya penerapan manajemen kurikulum yang konsisten dan konsekuen pula, yaitu terkait proses perencanaan, pengorganisasian, pelaksanaan, dan evaluasi (pengendalian). 
Implementasi Pendidikan Agama Islam pada TK/PAUD ABA AlIslah

Implementasi Pendidikan Agama Islam pada TK/PAUD ABA Al-Islah yang tidak dengan secara spesifik pada jam pembelajaran di luar pembelajaran reguler di kelas merupakan hal yang wajar. Sebab, TK ABA Al-Islah adalah sebuah lembaga pendidikan PAUD yang sudah bercirikan religius (Islam). Terlebih lagi TK/PAUD tersebut merupakan milik yayasan di bawah Aisyiyah yang secara umum dimengerti sebagai sebuah lembaga pendidikan keagamaan Islam, di samping melaksanakan pembelajaran yang sesuai sistem yang ditetapkan pemerintah (Kemendikbud) juga melaksanakan sistem pembelajaran yang digariskan oleh yayasan dalam hal ini Aisyiyah.

Dalam rangka sistimatisasi sistem pembelajaran pada TK/PAUD ABA Al-Islah, sebagaimana lazimnya pada lembaga-lembaga pendidikan formal lainnya, sekolah tersebut sudah membuat program pembelajaran secara runtut dan terstruktur. Kenyataan tersebut dapat diketahui dari sudah disusunnya kurikulum Pendidikan Agama Islah sesuai dengan Kurikulum 2013 dan ke-Aisyiyah-an. Kemudian, berdasarkan kurikulum tersebut disusun Program Semester (Promes), Rencana Pelaksanaan Program Mingguan (RPPM), dan Rencana Pelaksanaan Program Harian (RPPH).

Perpaduan kedua kurikulum di atas semakin meneguhkan bahwa TK/PAUD ABA Al-Islah merupakan lembaga PAUD yang cukup kuat pendidikan religiusitasnya. Jika menilik Kurikulum Tahun 2013 untuk PAUD dimana poin pertama pelaksanaan pembelajarannya adalah pengembangan Nilai Agama dan Moral (NAM) untuk peserta didik, maka semakin kuatlah pendidikan agama (Islam) pada sekolah tersebut karena diintegrasikan dengan materi yang berdasarkan kurikulum keAisyiyah-an dan ke-Muhammadiyahan.

Pendidikan Agama Islam pada TK/PAUD ABA Al-Islah pada tataran implemetatifnya merupakan integrasi dari Kurikulum 2013 dengan Aisyiyah yang dioperasionalkan melalui: (1) pembiasaan sehari-hari, seperti datang dan pulang mengucapkan salam, (2) membaca doa sehari-hari, (3) membaca surat-surat pendek, (4) praktik wudhu dan azan, (5) membaca bacaan salat, (6) prkatik salat berjamaah, (7) praktik infaq untuk qurban, (8) sifat jujur, (10) hadits-hadits pendek, (11) asma'aul husna, dan (12) nama-nama surat dalam Alquran.

$$
\text { Realitas implementasi }
$$

Pendidikan Agama Islam pada TK/PAUD ABA Al-Islah merupakan prinsip yang utama, karena lembaga tersebut merupakan sebuah lembaga pendidikan yang eksistensinya di bawah yayasan keagamaan Islam, yaitu Aisyiyah. Meskipun demikian impelementasi pendidikan secara umum (non keagamaan Islam) bukanlah merupakan faktor sekunder. Terbukti implementasi Pendidikan Agama Islam terintegrasi dengan pendidikan lainnya (umum) yang berstandarkan pada kurikulum untuk PAUD nasional, yaitu Kurikulum Tahun 2013 PAUD. 
Mencermati implementasi Pendidikan Agama Islam pada TK/PAUD ABA Al-Islah tampak bahwa proses pengembangan nilainilai agama Islam dan moral bagi peserta didik berdasarkan dua versi kurikulum, yaitu kurikulum 2013 PAUD dan yayasan. Dalam rangka mencapai tujuan pendidikan yang telah dicanangkan pada TK tersebut, maka sekolah juga menerapkan sistem full day school.

Kegiatan full day school, peserta didik TK/PAUD ABA AlIslah lebih banyak diarahkan dan dibimbing oleh ketiga pembimbing kepada pembiasaan-pembiasaan, hal itu bertujuan agar peserta didik menjadi terbiasa melakukan kegiatan di rumahnya sebagaimana yang sudah dibiasakan di sekolah, seperti cuci kaki dan tangan sebelum tidur siang, berdoa sebelum dan sesudah bangun tidur, praktik salat dengan bacaannya, bermain, dan sebagainya.

Pendidikan Agama Islam yang dilaksanakan pada TK/PAUD ABA Al-Islah sebagaimana disinggung diatas merupakan langkah yang ditempuh oleh sekolah dalam mewujudkan tercapainya tujuan pendidikan yang sudah dicanangkan, yaitu: membantu meletakkan dasar ke arah perkembangan akhlak, sikap, perilaku, pengetahuan, dan daya cipta yang diperlukan agar menjadi pribadi muslim yang tangguh, menghayati, dan mengamalkan ajaran Islam serta sanggup menyesuaikan diri dengan lingkungan dalam rangka pertumbuhan dan perkembangannya.

Perlu dikemukakan disini pula bahwa prinsip pembelajaran di TK/PAUD ABA Al-Islah adalah lebih mengacu kepada upaya mengembangakan kearifan lokal. Hal itu terlihat dari program yang menjadi unggulannya, yaitu sekolah sayur. Mengapa program unggulannya semacam itu? jawabannya adalah bahwa di lingkungan dimana TK/PAUD ABA Al-Islah berada merupakan kampung wisata sayuran dan tanaman, yaitu di daerah Rejowinangun, Kotagede Yogyakarta.

Model pembelajaran yang diterapkan pada TK/PAUD ABA AlIslah adalah kelompok (cooperative learning). Prinsip dasar pembelajaran dengan model kelompok dimaksudkan untuk mengeleminir adanya perbedaan-perbedaan diantara peserta didik, seperti peserta didik yang kemampuan belajarnya dalam kategori rendah, sedang, dan tinggi; asal ras peserta didik, budaya, dan bahkan jenis kelamin. Dengan demikian dapat terwujud model pembelajaran yang interaktif, komunikatif, friendly, dan harmoni diantara anggota kelompok. Pada akhirnya dapat tercipta sistem pembelajaran yang saling membantu, toleransi, dan kerjasama diantara peserta didik dalam anggota kelompoknya.

Standar Tingkat Pencapaian Perkembangnan Anak (STTPA) adalah merupakan kriteria minimal tentang kualifikasi perkembangan peserta didik yang mencakup aspek nilai agama dan moral, fisik, motorik, kognitif, bahasa, sosialemosional, dan seni. Terkait dengan penelitian pada TK ABA Al-Islah ini fokusnya adalah perkembangan peserta didik dalam aspek nilai agama dan moral. Pada sekolah tersebut berdasarkan pencermatan peneliti melalui wawancara, 
pengamatan, dan telaah dokumen, ternyata STPPA khususnya pada aspek nilai agama dan moral yang dikembangkan sesuai dengan STPPA yang digariskan oleh kurikulum tahun 2013 PAUD dan Kurikulum Yayasan Aisyiah.

STPPA dalam Kurikulum Tahun 2013 PAUD nilai agama dan moral meliputi: (1) mengenal agama yang dianut, (2) mengerjakan ibadah, (3) berperilaku jujur, (4) penolong, (5) sopan, (6) hormat, (7) sportif, (8) menjaga kebersihan diri dan lingkungan, (9) mengetahui hari besar agama, dan menghormati (toleransi) agama orang lain. Sedangkan STPPA nilai agama dan moral dalam kurikulum yayasan meliputi antara lain : (1) membaca surat-surat pendek, (2) praktik wudhu dan azan, (3) praktik infaq untuk qurban, (4) sifat jujur, (5) hadits-hadits pendek, (6) asma'aul husna, dan (7) nama-nama surat dalam Alquran.

Integrasi pengembangan nilainilai agama Islam dan moral yang bersumber dari Kurikulum Tahun 2013 PAUD dengan Kurikulum Yayasan Aisyiyah dimuka jika dicermati bahwa nilai-nilai agama dan moral versi kurikulum yayasan lebih memperkuat nilai-nilai agama dan moral yang dikembangkan oleh kurikulum tahun 2013 PAUD, sedangkan yang agak membedakan adalah bahwa pada kurikulum yayasan itu arah dan spesifikasinya pada pengembangan nilai-nilai keMuhammadiyah-an dan/atau ke'Aisyyah-an.

Jadi kombinasi pengembangan nilai-nilai agama Islam dan moral yang bersumber dari versi kurikulum tahun 2013 PAUD dan Yayasan pada
TK/PAUD ABA Al-Islah merupakan deskripsi bahwa sekolah tersebut mentaati aturan permainan sistem pendidikan nasional (khususnya PAUD), yaitu Undang-undang Sistem Pendidikan Nasional Nomor 20 Tahun 2003 dan begitu juga mentaati aturan permainan sistem pendidikan (khususnya PAUD) menurut organisasi Yayasan Muhammadiyah dan Aisyiyah. Penerapan kedua produk kurikulum pada sekolah tersebut terbukti dapat berjalan dengan baik dan bahkan saling memperkuat kualitas pengembangan nilai-nilai agama Islam dan moral bagi peserta didik.

\section{Implementasi Pendidikan Agama Islam pada TK/PAUD Laboratori Pedagogia

Implementasi Pendidikan

Agama Islam pada TK/PAUD Laboratori Pedagogia agak berbeda dengan TK/PAUD ABA Al-Islah. Implementasi Pendidikan Agama Islam pada TK tersebut tidak terintegrasi dengan implementasi pembelajaran reguler di kelas. Maksudnya, Pendidikan Agama Islam diberikan kepada peserta didik pada hari-hari tertentu (Senin, Rabu, dan Jumat). Kegiatan pembelajaran Pendidikan Agama Islam pada sekolah tersebut dilaksanakan pada pagi hari dari jam 08.30-10.00 WIB dengan dua orang pendidik.

Proses

pembelajaran

Pendidikan Agama Islam pada TK/PAUD Laboratori Pedagogia memang tidak diberikan secara terintegrasi dengan pelaksanaan pembelajaran reguler di kelas, namun dalam proses pembelajaran setiap hari nilai-nilai agama Islam maupun moral secara tidak langsung juga 
sudah tersampaikan kepada peserta didik. Hanya saja pembelajaran Pendidikan Agama Islam yang secara khusus diberikan di luar jam pembelajaran reguler yang jam harinya sebagaimana disinggung diatas.

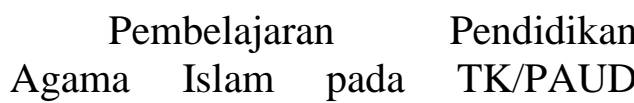
Laboratori Pedagogia untuk anak usia 5-6 tahun pada pagi hari, jam 08.30-10.00 WIB. minggu pertama materi yang diberikan kisah tokoh agama Islam, Minggu kedua akidah, minggu ketiga praktik ibadah, dan minggu keempat hafalan surat-surat pendek dan doa sehari-hari. Kemudian untuk pembelajaran materi iqra' diberikan tiga kali seminggu pada sore hari oleh tiga ustadzah.

Dengan demikian dapat disimplifikasikan bahwa pembelajaran Pendidikan Agama Islam pada TK/PAUD Laboratori Pedagogia dilaksanakan di luar jam pembelajaran reguler di kelas. Adapun pembelajaran Pendidikan Agama Islam pada sekolah tersebut dilaksanakan pada jam dan hari tersendiri dan ditambah dengan pembelajaran iqra' yang diberikan pada sore hari. Kemudian untuk penguatan dan pembiasaan nilai-nilai agama Islam dan moral kepada peserta didik, pada TK/PAUD tersebut juga melaksanakan full day school. Hanya saja peserta didik yang mengikuti kegiatan pembelajaran iqra' dan penguatan serta pembiasaan nilai-nilai agama dan moral tersebut tidak semuanya, tetapi hanya sekitar $50 \%$ dari peseta didik kelas B1 dan B2.

$$
\text { Implementasi Pendidikan }
$$

Agama Islam pada TK/PAUD
Laboratori Pedagogia sudah mendapatkan layanan yang baik dari penyelenggaranya, mengingat peserta didik pada sekolah itu hampir seluruhnya beragama Islam. Hal itu terbukti pihak sekolah menyediakan pendidik untuk Pendidikan Agama Islam yang cukup memadai dilihat dari segi kuantitas maupun kompetensinya. Meskipun demikian, bukan berarti sekolah tersebut tidak memberikan layanan yang baik pula kepada peserta didik yang beragama non Islam (Katolik) yang jumlahnya hanya 15 orang. Peserta didik yang beragama Katolik pelayanan pendidikannya diampu oleh seorang guru TK/PAUD Laboratori Pedagogia yang beragama Katolik.

Model pembelajaran yang dikembangkan pada TK/PAUD Laboratori Pedagogia adalah model pembelajaran kelompok, dengan memasukkan peserta didik ke dalam 4 kegiatan main dan setiap kegiatan inti setiap kelompok melakukan kegiatan main yang berbeda-beda. Khusus untuk implementasi Pendidikan Agama Islam kegiatan pembelajarannya secara klasikal, yakni dibedakan antara kelompok kelas B1 dan B2. Selain itu pada pembelajaran iqra' juga dilaksanakan secara kelompok.

Standar Tingkat Pencapaian Perkembangnan Anak (STTPA) adalah merupakan kriteria minimal tentang kualifikasi perkembangan peserta didik yang mencakup aspek nilai agama dan moral, fisik, motorik, kognitif, bahasa, sosialemosional, dan seni. Terkait dengan penelitian pada TK/PAUD Laboratori Pedagogia fokusnya sama dengan di TK/PAUD ABA Al-Islah, yaitu perkembangan peserta didik 
dalam aspek nilai agama dan moral. Berdasarkan pencermatan peneliti melalui wawancara, pengamatan, dan telaah dokumen, ternyata STPPA khususnya pada aspek nilai agama dan moral yang dikembangkan sesuai dengan STPPA yang digariskan oleh kurikulum tahun 2013 PAUD. STPPA dalam kurikulum tahun 2013 PAUD nilai agama dan moral meliputi: (1) mengenal agama yang dianut, (2) mengerjakan ibadah, (3) berperilaku jujur, (4) penolong, (5) sopan, (6) hormat, (7) sportif, (8) menjaga kebersihan diri dan lingkungan, (9) mengetahui hari besar agama, dan menghormati (toleransi) agama orang lain.

Jadi, Pendidikan Agama Islam pada TK/PAUD Laboratori Pedagogia berdasarkan Kurikulum Tahun 2013 PAUD yang implementasi pembelajarannya di luar kegiatan pembelajaran reguler di kelas secara spesifik. Tetapi implementasi Pendidikan Agama Islam dilaksanakan pada hari dan jam tersendiri di luar jam pembelajaran reguler di kelas. Sedangkan pendidik untuk pembelajaran Pendidikan Agama Islam, pihak sekolah mendatangkan dari luar yang dilihat dari kompetensi profesionalnya sudah tepat, yaitu sarjana Pendidikan Agama Islam dan ustadz dari pondok pesantren. Begitu juga untuk pembelajaran iqra' dan kegiatan fullday school juga mendatangkan pembina dari luar. Dengan demikian implementasi Pendidikan Agama Islam pada TK ini dapat berjalan dengan baik dan memenuhi prinsip kriteria STPPA.

\section{Faktor Pendukung dan Penghambat}

Pada kedua lembaga PAUD (TK ABA Al-Islah dan TK Laboratori Pedagogia), masingmasing penyelenggara (yayasan) merupakan faktor pendukung utama implementasi pendidikannya, khususnya dalam hal ini implementasi Pendidikan Agama Islam. Oleh karena kebijakankebijakan kedua yayasan TK tersebut mempunyai otoritas tertinggi dalam penyelenggaran sistem pendidikan yang dilaksanakan.

TK ABA Al-Islah yang berada di bawah payung Yayasan Aisyiyah dengan jumah pendidik dan tenaga kependidikan yang memadai serta seluruh warga sekolah sebagai pemeluk agama Islam, maka faktor tersebut sangat mendukung bagi upaya pengembangan dan implementasi Pendidikan Agama Islam. Sedikit berbeda dengan TK Laboratori Pedagogia yang tenaga pendidik dan tenaga kependidikan serta warga sekolahnya juga terdapat pemeluk agama non Islam, maka pihak sekolah juga harus ada kebijakan pelayanan pendidikan agama yang non Islam. Meskipun demikian karena pemeluk agama Islam warga sekolah TK Laboratori Pedagogia merupakan jumlah mayoritas, maka hal itu juga menjadi salah satu faktor pendukung terhadap implementasi Pendidikan Agama Islam di sekolah tersebut.

Kompetensi dan integritas para pendidik pada kedua TK di atas (TK ABA Al-Islah dan TK Laboratori Pedagogia) terkait dengan pendidikan agama, khususnya Pendidikan Agama Islam juga merupakan faktor pendukung yang 
sangat menentukan. Hal itu tidak lepas dari dasar implementasi pendidikan agama untuk PAUD adalah dari Kurikulum Tahun 2013. Dalam kurikulum tersebut dijelaskan bahwa Standar Tingkat Pencapaian Perkembangan Anak (STPPA) merupakan kriteria minimal tentang kualifikasi perkembangan anak yang salah satunya adalah mencakup aspek nilai agama dan moral. Oleh karena itu kedua sekolah tersebut secara sungguh-sungguh memberikan pelayanan pendidikan agama bagi peserta didik, khususnya dalam hal ini Pendidikan Agama Islam.

Mengingat kedua lembaga TK/PAUD di atas sebagai lembaga pendidikan anak usia dini percontohan (gugus), maka segala keperluan yang dibutuhkan untuk memenuhi kepentingan pelaksanaan pendidikan termasuk Pendidikan Agama Islam sudah memenuhi standar kriteria sebagai sekolah percontohan, seperti adanya Kelompok Bermain (KB), Tempat Penitian Anak (TPA), Taman Kanakkanak (TK) dengan dikung fasilitas yang memadai. Dengan demikian dapat dikatakan hampir tidak ada penghambat (kendala) dalam implementasi pendidikan, khususnya Pendidikan Agama Islam pada kedua sekolah tersebut.

\section{PENUTUP}

Berdasarkan hasil penelitian dan pembahasannya, dapat ditarik simpulan sebagai berikut: Nilai-nilai agama Islam dan moral yang dikembangkan pada TK/PAUD ABA Al-Islah dan TK/PAUD Laboratori Pedagogia berbasis pada Kurikulum tahun 2013 untuk PAUD. Pada kedua sekolah tersebut juga ada beberapa materi di luar kurikulum 2013 yang menjadi diprogramkannya, yaitu : (1) hafalan doa sehari-hari, (2) hafalan surat-surat pendek dari Alquran, (3) ayat-ayat pilihan, kalimah thayyibah, (4) Alquran dan Hadis, (5) ibadah praktis, (6) iqra', dan (7) pembisaanpembiasaan perilaku. Sedikit yang agak membedakan antara kedua TK/PAUD tersebut adalah bahwa TK/PAUD ABA Al-Islah juga menggunakan materi ke-Aisyiyah-an dan ke-Muhammadiyah-an. Sedangkan pada TK/PAUD Laboratori Pedagogia Implementasi nilai-nilai agama Islam dan moral pada peserta didik TK ABA Al-Islah dan TK Laboratori Pedagogia lebih cenderung kepada pembiasaanpembiasaan dalam perilaku seharihari di sekolah seperti berdoa sebelum dan sesudah pembelajaran, cuci tangan sebelum makan, berdoa sebelum dan sesudah makan, berdoa dan praktik berwudu, dan sebagainya.

$$
\text { Pada kedua lembaga PAUD }
$$

(TK ABA Al-Islah dan TK Laboratori Pedagogia), masingmasing penyelenggara (yayasan) merupakan faktor pendukung utama implementasi pendidikannya, khususnya dalam hal ini implementasi Pendidikan Agama Islam. Kompetensi dan integritas para pendidik pada kedua TK/PAUD di atas (TK/PAUD ABA Al-Islah dan TK/PAUD Laboratori Pedagogia) terkait dengan pendidikan agama, khsusnya Pendidikan Agama Islam juga merupakan faktor pendukung yang sangat menentukan. Kedua lembaga TK/PAUD tersebut sebagai lembaga pendidikan anak usia dini 
percontohan (gugus). Oleh karena itu tidak ada penghambat (kendala) dalam implementasi pendidikan, khususnya Pendidikan Agama Islam pada kedua sekolah tersebut.

\section{DAFTAR PUSTAKA}

Buku Proses Pembelajaran dan Kurikulum TK ABA Al-Islah Yogyakarta, 2017/2018.

Dokumen Kurikulum Taman KanakKanak TK Laboratori Pedagogia Yogyakarta Tahun Pelajaran $2017 / 2018$ Terakreditasi.

Kurikulum Taman Kanak-Kanak TK Laboratori Pedagogia Yogyakarta Tahun Pelajaran 2017/2018.

Mudyahardjo. 2002. Filsafat Ilmu Pendidikan. Bandung: Remaja Rosdakarya.

Paud-dikmas.kemendikbud.go.id, diakses pada tanggal 27 Desember 2017.

Permendikbud Nomor 137 Tahun 2014 Tentang Standar Nasional Pendidikan Anak usia Dini.

Profil TK ABA Al-Islah Tahun Ajaran 2017.

Profil TK Laboratori Pedagogia FIP YNY, Tahun Ajaran 20172018.

Satori, Djam'an. 2007. Profesi Keguruan. Jakarta: UT.

Sugiyono. 2013. Metode Penelitian Manajamen, Pendekatan: Kuantitatif, Kualitatif, Kombinasi (Mix Methods), Penelitian Tindakan (Action
Research, dan Penelitian Evalusi. Bandung: Alfabeta.

Tim Penyusun Kamus Pusat Pembinaan dan Pengembangan Bahasa Depdikbud. 1989. Kamus Besar Bahasa Indonesia. Jakarta: Balai Pustaka.

Undang-Undang Nomor 20 tahun 2003 Tentang Sistem Pendidikan Nasional.

Wahab, 2008. Pelaksanaan Kurikulum Tingkat Satuan Pendidikan (KTSP) pada Madrasah Aliyah. Semarang: Balai Litbang Agama.

2008. Implementasi Manajemen Kurikulum pada Pondok Pesntren Salaf (Studi Kasus pada Madrasah Diniyah Ali Maksun KrapyakBantul-Daerah Istimewa Yogyakarta). Semarang: Balai Litbang Agama. 2011. Kinerja Guru Agama Madrasah Aliyah Pasca Diklat Fungsional pada Balai Diklat Semarang (Evaluasi Kinerja Guru Agama Madrasah Aliyah Pasca Diklat Fungsional di Daerah Istimewa Yogyakarta). Semarang: Balai Litbang Agama.

Zuhairini. 2000. Metodik Khusus Pendidikan Agama. Surabaya: Usaha Nasional. 